\title{
HumAN CUTANEOUS LEISHMANIASIS: ULTRASTRUCTURAL INTERACTIONS BETWEEN THE INFLAMMATORY CELLS AND LEISHMAN BODIES IN THE SKIN LESIONS
}

\author{
EL-SHOURA S.M.*, TALLAB T.** \& BAHAMDAN K.**
}

\section{Summary :}

The ultrastructural interactions between the inflammatory infiltrate and Leishman bodies (LBs) were described in skin lesions from 16 patients with acute cutaneous leishmaniasis. In early stages of the inflammation, the cellular infiltrate consisted of both undifferentiated and differentiated (activated) monocytes ( $M$ ), macrophages (MC), multinucleated giant cells (MNGC), plasma cells (PC), lymphocytes (Ly), and fibroblasts (F). In late stages, the infiltrate was in the form of tuberculous granulomas consisted mainly of type I secretory, and type I| vesicular epithelioid cells (ECs), in addition to remnant of some inflammatory cells seen in the early stages. The two types of ECs were found only in six patients. The activated M, Mc and MNGC were often parasitized by LBs. The parasites were enclosed within the host cell digestive vacuoles (DVs), or phagolysosomes, together with skin melanosomes which are known to have lysosomal effect. In the DVs, LBs either survived or were killed and expelled from the host cell cytoplasm. This study showed, for the first time, that the melanosomes were apparently involved in killing of the LBs possibly by increasing the fatal effects of the DVs hydrolytic enzymes. Plasma cells were packed with large "Russell's bodies" indicating a high cellular immunoglobulin activity. The large, granular lymphocytes were in close contact to the activated $M$, possibly to promote delivery of activation signals. The type I secretory ECs contained mucin-like granules with electrondense cores. In late stages of inflammation, the type II vesicular ECs contained lysosomal granules, and were found together with the type I ECs in broken-down tuberculous granulomas. The type | secretory ECs were previously thought to produce a mediator, or " granuloma factor " which recruits undifferentiated mononuclear cells to perpetuate the granulomatous process; while the type II vesicular ECs were thought to appear where the granulomatous process in brought to an end, preceeding the healing by fibrosis.

KEY WORDS : cutaneous leishmaniasis, human, cellular infiltrate, inflammation, ultrastructure.

MOTS CLÉS : leishmaniose cutanée, homme, infiltrat cellulaire, inflammation, ultrastructure.
Résumé : LeISHMANIOSE CUTANÉE HUMAINE : INTERACTIONS ENTRE INFILTRAT INFLAMMATOIRE ET CORPS DE LEISHMAN DANS LES LÉSIONS CUTANÉES

Les interactions entre infiltrat inflammatoire et corps de Leishman (LBs) sont décrites en microscopie électronique dans les lésions cutanées de 16 malades atteints de leishmaniose cutanée aiguë. Dans les premiers stades de l'inflammation, l'infiltrat cellulaire consiste à la fois en monocytes indifférenciés et différenciés (M), en macrophages (MC), en cellules géantes multinuclées (MNGC), en plasmocytes (PC), en lymphocytes (Ly) et en fibroblastes (F). Dans les stades avancés, l'infiltrat est sous forme de granulomes tuberculeux consistant en cellules épithélioides de type I secrétoire et de type II vésiculaire (ECs), en plus de quelques cellules inflammatoires observées au cours des premiers stades. Les deux types ECs n'ont été trouvés que chez six malades. Les Mactivés, les Mc et les MNGC sont souvent parasités par les LBs. Les parasites sont inclus dans les vacuoles digestives (DVs) de la cellule hôte ou des phagolysosomes avec des mélanosomes cutanés qui sont connus pour avoir une action lysosomiale. Dans les DVs, les LBs sont soit en survie, soit morts soit expulsés du cytoplasme de la cellule hôte. L'étude montre, pour la première fois, que les mélanosomes semblent intervenir pour tuer les LBs, peutêtre en augmentant les effets léthaux des enzymes hydrolytiques des DVs. Les plasmocytes sont agglomérés avec de grands " corps de Russell ", indiquant une grande activité des immunoglobulines cellulaires. Les grands lymphocytes granuleux sont en contact étroit avec les $M$ activés, probablement pour déclencher les signaux d'activation. Les ECs de type I secrétrices contiennent des granules comparables à de la mucine avec des noyaux denses. Au cours des derniers stades de l'inflammation, les ECs de type II vésiculaires contiennent des granules lysosomaux, et coexistent avec les ECs de type I dans des granulomes tuberculeux éclatés. Il était admis précédemment que les ECs de type / secrétoire produisaient un médiateur "granuloma factor " qui recrute des mononucléaires indifférenciés afin de perpétuer le processus granulomateux; les ECs type II vésiculaire sont interprétés comme n'apparaissant qu'à la fin du processus granulomateux, précédant la guérison par fibrose.

\section{INTRODUCTION}

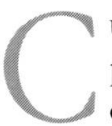

utaneous leishmaniasis, or Oriental Sore, is a parasitic skin disease endemic in several regions of the world including Saudi Arabia (Beaver et

\footnotetext{
* Department of Pathology and

** Division of Dermatology, College of Medicine, King Saud University, Abha, P.O. Box 641, Kingdom of Saudi Arabia.

Correspondence: S.M. El-Shoura.
}

al., 1984). The parasite is introduced into the human skin as a promastigote (flagellate) form while an infected sand fly, Phlebotomus papatasi, is taking a blood meal. Then the parasite must successfully be engulfed by a macrophage, in which the parasite is transformed into the more resistant to intracellular killing amastigote (aflagellate) form (Murray, 1982; Pearson et al., 1983), to multiply, and escape from rupturing macrophages. The parasite new generations are taken up by other phagocytes in the immediated vicinity. 
In early stage, the lesion is characterized by the proliferation of macrophages that contain numerous amastigotes, and a variable infiltration of lymphocytes and plasma cells. As the lesion heals, the macrophages and organisms gradually diminish in number and the lymphocytes and plasma cells increase. Severe ulceration follows, and healing occurs in the presence of a nonspecific granulation tissue (Hutt et al., 1973).

Despite a few, brief histopathological and immunohistochemical studies have been published on cutaneous leishmaniasis (Esterre et al., 1992; Mansour et al., 1993), majority of these studies were carried out in vitro on laboratory animals. However, little is known about the ultrastructural interactions between the leishman parasite and defensive cells in the human skin lesion (Ridley \& Wells, 1986), in comparison to other various investigations which were focused mainly on visceral leishmaniasis (El-Shoura, 1992, 1994; El-Shoura \& Sheikha, 1991; El-Shoura et al., 1993). This is the aim of the present study.

\section{MATERIALS AND METHODS}

S kin biopsies were taken from 16 untreated patients (9 $\mathrm{M}+7 \mathrm{~F}$ ), aged 12-55 (mean 33.7), who were seen at the Leishmania Clinic, Asir Central Hospital, the South West region of Saudi Arabia, because of infection with cutaneous leishmaniasis. The diagnosis of Oriental Sore was confirmed by microscopic examination and cultures. In addition, the parasite structure was identical to that identified as Leishmania tropica (Pham et al., 1970). Biopsies were cut into small pieces, $2-3 \mathrm{~mm}^{3}$ each, and immediately fixed in $2.5 \%$ glutaraldehyde buffered in $0.1 \mathrm{M}$ sodium cacodylate, $\mathrm{pH} 7.3$, at the room temperature, for $3 \mathrm{~h}$. Samples were postfixed in $1 \%$ osmium tetroxide for $1 \mathrm{~h}$, washed twice in buffer, dehydrated in an ascending series of ethanol, and embedded in Epoxy resin via propylene oxide. Semithin sections $(0.5 \mu \mathrm{m})$ were stained with toluidine blue. Ultrathin sections were stained with uranyl acetate and lead citrate, and examined in Jeol 1200 EX Transmission Electron Microscope (TEM) at $80 \mathrm{kV}$.

\section{RESULTS}

I n semithin sections, the epidermal layer appeared thin with loss of rete-ridges and infiltrated with many amastigotes, or leishman bodies (LBs). The dermis showed massive inflammatory infiltrate including undifferentiated and differentiated monocytes and identical macrophages containing several LBs, in addition to plasma cells and lymphocytes. Parasites were also detected between the inflammatory cells surrounding the sweat glands. In six patients $(4 \mathrm{M}+2 \mathrm{~F})$ aged 22-38 (mean 29.5), the dermal layer showed, in addition to the previously described inflammatory cells, several epithelioid cells forming tuberculous granulomas. Blood vessels and capillaries showed thickening of their walls, while the endothelial cells appeared swollen and undergoing proliferation. In ultrathin sections, many intra- and extra-cellular parasites were detected between the inflammatory cells.

\section{MONOCYTE-MACROPHAGE-MULTINUCLEATED GIANT CELL SYSTEM}

The few, small, undifferentiated monocytes characterized by smooth cell surface and cytoplasm poor in cell organelles. Monocytes were either found scattered between the inflammatory cells, or were seen squeezed between multinucleated giant cells (MNGC) (Fig. 1). These were parasitized by numerous (up to 28) LBs, which were accumulated in large parasitophorous vacuoles (PVs) (Fig. 1), and seemed to be newly internalized LBs. While some parasites were capable to survive, others were seen killed in the DVs and appeared as " ghost cells " (Fig. 1). Considerable number of large, well differentiated (activated) monocytes as indicated by the presence of surface projections and cytoplasm rich in cell organelles including mitochondria and small vacuoles were parasitized by a few LBs (Fig. 2). The latter were often enclosed within the monocytes PVs, or phagosomes. Most of the plentiful, large skin macrophages formed MNGC possessing, electrondense, round, lysosomal granules, and short cisternae of rough endoplasmic reticulum (RER), in addition to large digestive vacuoles (DVs), or phagolysosomes (Figs. 3, 4). These were possibly formed by the fusion of secondary lyposomes with PVs (Alexandria \& Vickerman, 1975). The DVs contained round to oval shaped LBs in addition to several electron-dense melanosomes (Figs. 3, 4). The LBs and melanosomes were arranged peripherally in the DVs, but the parasites were in such position as if pushing their cell bodies against the DVs limiting-membrane, trying to penetration into the cell cytoplasm (Fig. 3). In Figure 4, one of the parasite was capable to do so. Large bundles of collagen fibers were also found to be phagocytosed by macrophages (Fig. 3).

\section{Plasma Cells}

These predominant cells appeared in two different ultrastructural features, the first characterized by cytoplasm rich in whored cisternae of RER, a few scattered small granules, and mitochondria, in addition to large eccentric nuclei (Fig. 5). The other feature characte- 

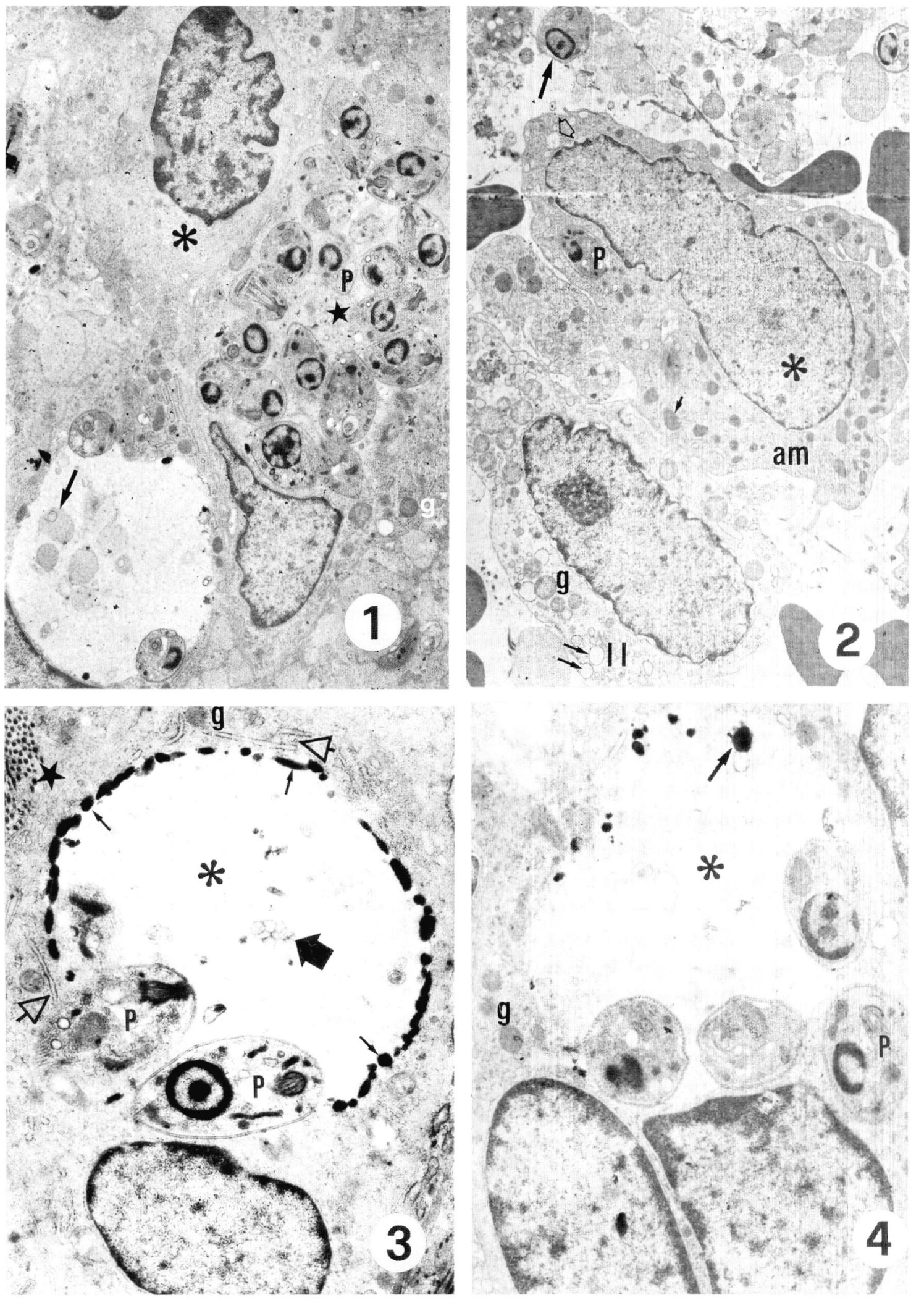

Fig. 1. - An undifferentiated monocyte (asterisk) squeezed between macrophages involved in the formation of a multinucleate giant cell. Note the newly internalized parasites ( $p$ ) within the host parasitophorous vacuole (star). Note also that two parasites are still survived in the digestive vacuole, while dead ones appear as " ghost " cells (arrow), g, lysosomal granules. $\times 12$ 000. Fig. 2. - Differentiated (activated) monocyte (am) with large nucleous (asterisk) and cytoplasm containing several mitochondria (short arrow) and vacuoles (empty arrow). Note that the parasite (p) is surrounded by a closely applied parasitophorous vacuole. A type II ECs (II) with cytoplasm filled with vesicles (two arrows) and lysosomal granules (g). Single arrow points to an extracellular parasite. $\times 8000$. Fig. 3. - A part of multinucleated giant cell containing cytoplasmic lysosomal granules (g), short cisternae of rough endoplasmic reticulum (empty head arrows) and a large digestive vacuole (asterisk). Note the two parasites ( $\mathrm{p}$ ) pushing their cell body against the vacuole limiting-membrane. Note also the melanosomes (three thin arrows) arranged peripherally in the vacuole, in the middle of which some of the discharged melanosomes that appear as empty vesicles (solid arrow). Star represents a phagocytosed bundle of collagen fibers. $\times 18000$. Fig. 4. - As in Figure 3 but one of the parasites (p) was able to escape into the host cell cytoplasm. g, lysosomal granules. Arrow points to a melanosome. Asterisk represents a digestive vacuole. $\times 18000$. 
rized by cytoplasm packed with either electron-dense, polygonal, "Russel's bodies "(Ghadially, 1988), of variable size (Fig. 6), indicating a cellular immunoglobuline activity, or semi-opaque tetragonal crystalloids with parallel intracrystalloid pattern (Fig. 7). These were often found in enormously distended cirternae of RER (Fig. 7).

\section{LYMPHOCYTES}

These few, scattered, large cells characterized by the high nuclear/cytoplasmic ratio. The narrow cytoplasmic areas contained free ribosomes, few electron-dense granules and mitochondria (Fig. 6). A close contact was observed between theses lymphocytes and the activated monocytes (Fig. 6).

\section{FiBROBLASTS}

The long fibroblasts with irregularly cell surface were always associated with collagen fibers (Fig. 8). A few, healthy looking and partially degenerated LBs were seen surrounded by a closely applied host membrane within the cell cytoplasm (Fig. 8), indicating the phagocytic activity of these cells. As in visceral leishmaniasis (El-Shoura \& Sheikha, 1991), the partially damaged LBs were indicated by vacuolations of both their cytoplasmic matrix and perinuclear membrane. In addition, melanosomes similar to those observed in the macrophage DV (Figs. 3, 4), were also detectable in the fibroblast cytoplasmic vacuoles (Fig. 8).

\section{Tuberculoid GRANULOMAS}

These consisted of two types of structurally different epithelioid cells (ECs): type I secretory and type II vesicular ECs. The oval-shaped type I were essentially secretory ECs and were packed with round mucin-like granules containing electron-dense cores (Fig. 9). Activated monocytes, plasma cells and lymphocytes were often associated with type I ECs particularly in severely damaged areas of the host tissue (Fig. 9). Type I ECs nuclei were irregular in outline (Fig. 9). These cells have never been seen parasitized by LBs.

The unhealthy-looking type II ECs contained highly vesicular cytoplasm (Fig. 2), possibly as an indication of broken-down ECs. This form of type II ECs together with type I ECs were often observed in dramatically damaged skin tissue (Fig. 10). These were associated with monocytes and typical epidermal Langerhans cells (LCs) (Fig. 10). Unlike observations by Black et al., 1993, the present LCs were non-phagocytic.

\section{DISCUSSION}

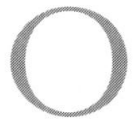

ur observations showed that, in patients with acute cutaneous leishmaniasis (CL), the early host tissue reaction was represented by inflammatory infiltrate composed of monocyte-macrophage system, plasma cells, lymphocytes, and fibroblasts, while the late reaction was represented by the appearance of tuberculoid granulomas consisting of two types of epithelioid cells (ECs). The activated monocytes, macrophages, and multinucleated giant cells (MNGC) were demonstrated to be parasitized by LBs. These intracellular parasites have to survive a barrage of macrophage microbicidal system which may include the lethal products of oxygen metabolism, lysosomal hydrolase, low $\mathrm{pH}$ and cationic proteins. As several organisms have developed mechanisms for avoiding contact with lysosomes, the LBs in the present study were shown to be arranged peripherally in digestive vacuoles (DVs) where they were pushing their cell bodies against to the parasitophorous vacuolelimiting membrane, as if trying to escape from the vacuole lethal contents into the host cell cytoplasma. This would tend to emphasize the microbicidal potential of the DV. However, our observations are similar to those described by Ridley \& Wells (1986). These authors demonstrated that, in the early lesions of $\mathrm{CL}$, the host macrophages were: 1) heavily parasitized and vesiculated, 2) undifferentiated, or 3) large and active, with fewer organisms. These authors have also added that extracellular parasites appeared to enhance, both the activation and lytic processes, but degradation of these parasites were associated with dendritic-like cells (DLCs) more than with macrophages. In the present study, typical epidermal Langerhans cells (LCs), which may be related to DLCs, (Chu et al., 1982; Murphy et al., 1983), have been demonstrated in association to type II epithelioid cells. Our observations are also similar to those described for Trypanosoma cruzi (Kress et al., 1975; Noguiera \& Cohn, 1976), which tend to escape from the PV to lie free in the host cell cytoplasm. For self protection, other parasites, e.g. Toxoplasma gondii inhibit the fusion of lysosomes to the PV (Jones \& Hirsh, 1972). Survival may then be due to the resistance of the parasites exposed surface to lysosome mediated denaturation and enzyme attack (Chang \& Dwyer, 1978), or, alternatively, the parasite may excrete inhibitors which prevent this attack (Lewis \& Peters, 1977). Paradoxically, it had been suggested that lysosomes may provide essential nutrients for these parasites that reside in DV (Brown et al., 1969), and labelled host cell secondary lysosome contents have been found within membrane bound vesicles in amastigotes of L. donovani and L. major (Berman et al., 1979, 1981). Melanosomes were detected, for the 

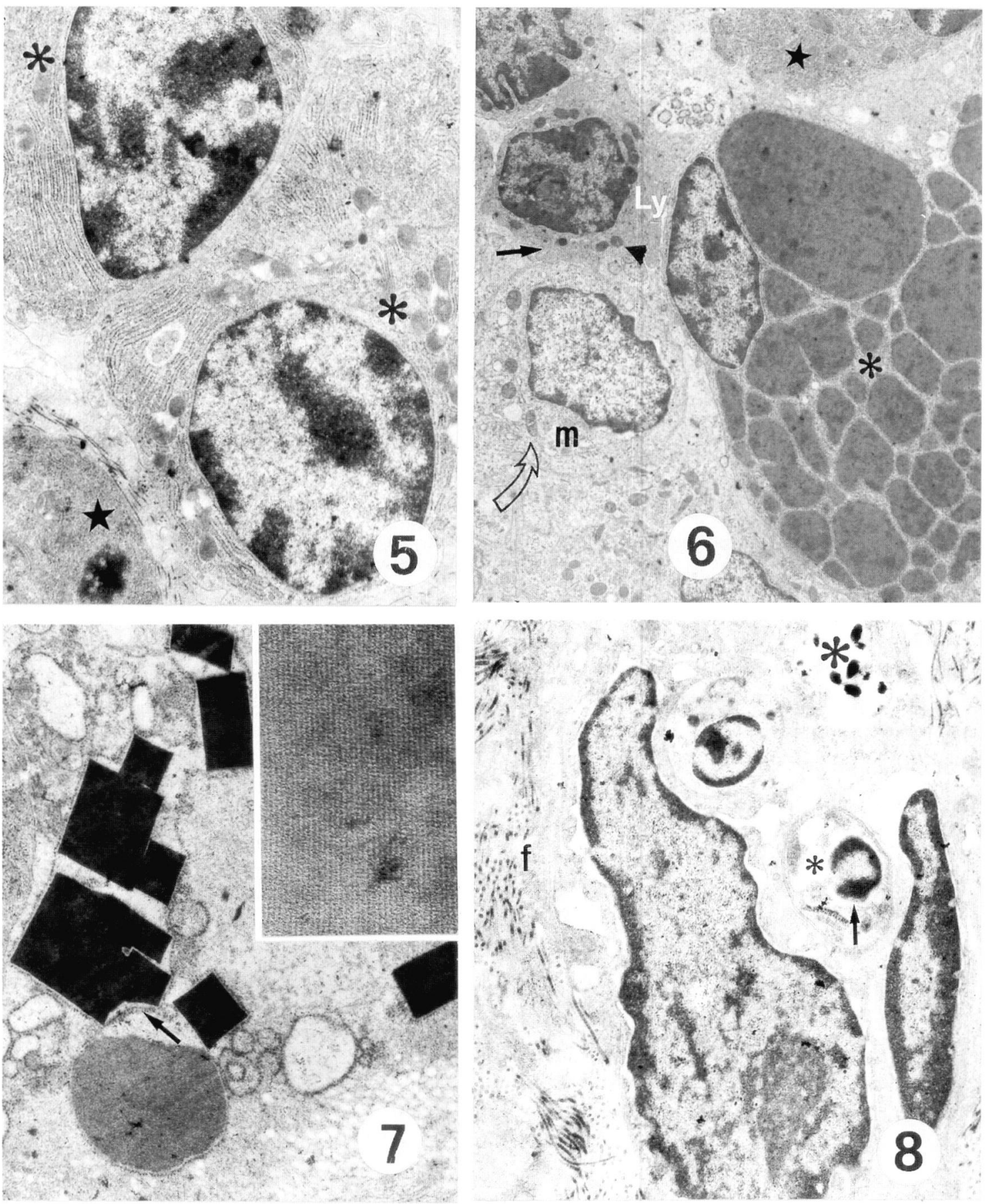

Fig. 5. - Two healthy-looking (asterisk) and a partially degenerated (star) plasma cells. $\times 12$ 000. Fig. 6. - A highly active plasma cell (asterisk) contains large "Russell's bodies ". Note the close contact (arrow) between a lymphocyte (ly) containing electron-dense granules (arrow head) and an activated monocyte $(\mathrm{m})$. Empty arrow points to mitochondria. Star represents a plasma cell. $\times 12$ 000. Fig. 7. - Plasma cell cytoplasm showing tetragonal crystalloids found in its dilated cisternae of RER (arrow). $\times 45500$. Inset: Higher magnification showing the parallel intracrystalline pattern. $\times 405225$. Fig. 8. - A fibroblast associated with collagen fibers (f). Note that one of the two demonstrated parasites appears healthy, while the other one appears partially degenerated as indicated by the parasite cytoplasmic (small asterisk) and perinuclear (arrow) vacuoles. Large asterisk represents a cytoplasmic vacuole containing melanosomes. $\times 16000$. 

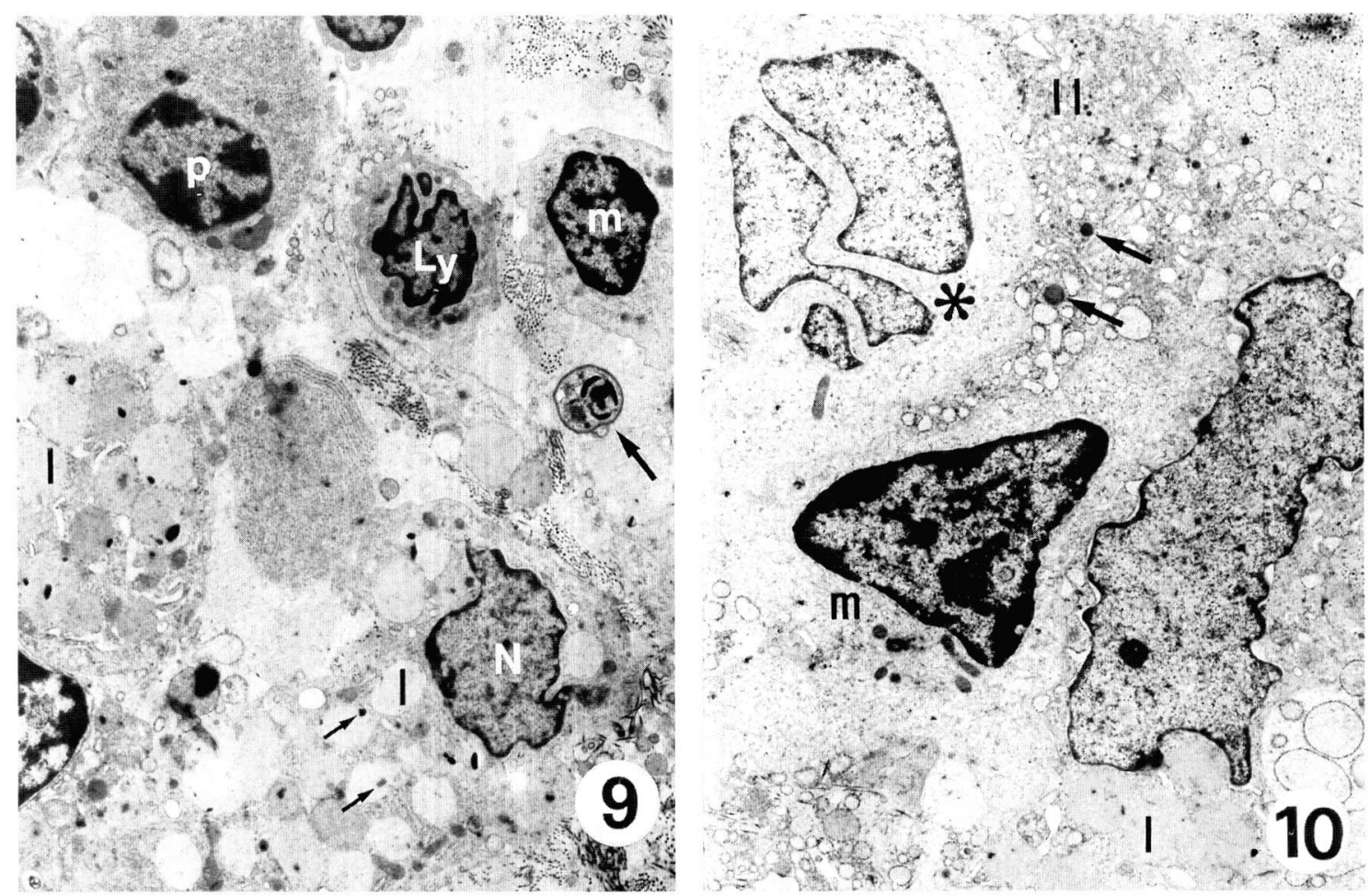

Fig. 9. - Type I secretory ECs packed with mucin-like granules containing electron-dense cores (two thin arrows). Ly, lymphocyte; m, an activated monocyte; N, type I EC nucleus; p, plasma cell. Single arrow points to an extracellular parasite. $\times 10$ 000. Fig. 10. - A brokendown tuberculous granuloma consisting of degenerated type I secretory and type II vesicular ECs and monocytes (m). Note the lysosomal granules (two arrows) in the vesicular type II ECs. Asterisk represents a non-parasitized Langerhans cell. $\times 12000$.

first time, together with the parasites within DVs of both macrophages and MNGC. The DVs have been demonstrated to contain acid phosphatase activity, therefore they were regarded as lysosomes (Horri et al., 1968). They are known to be found in normal keratinocytes, and in dermal macrophages, or melanophages, in some skin diseases (Ghadially, 1985).

The Russell's bodies seen in active plasma cells are known to be glycoprotein-rich bodies which formation is induced by immunonization (Ortega \& Mellors, 1957). These granules may also represent a storage form of the RER protein in certain disease such as cutaneous leishmaniasis. Plasma cells were demonstrated to release their granular contents on the parasite surface to attract macrophages (El-Shoura, 1993). However, it has been documented that the appearance of cell-mediated reactions is characterized by the presence of mononuclear cells whilst the presence of plasma cells is indicative of an antibody-mediated response (Smith, 1977).

A close contact between large granular lymphocytes and activated monocytes was observed. Similar observations were described as the cell-cell contacts between T-lymphocytes and macrophages that may promote delivery of activation signals from lymphocytes to the resting macrophages i.e. lymphokine-mediated activation (Esterre et al., 1992).
Leishman bodies (LBs) were seen surrounded by a closely applied host membrane within the skin fibroblasts, which are known to be non-phagocytic cells, while melanosomes were detected within the host cell cytoplasmic vacuoles. Leishmania species have been noted to infect human skin fibroblasts (Dedet et al., 1983; Schwatzman \& Pearson, 1985). The fate of LBs in fibroblasts is of interest from several prospectives. Fibroblasts are plentiful to the inoculation site and could provide sanction for the parasite to convert to a more resistant stage. Non-phagocytic cell lines, especially those with biochemical alterations could be used to define the conditions necessary for the conversion of promastigote (flagellate) form to amastigote (aflagellate) form, and possibly could explain the tissue tropisms of different leishmania species. However, LBs were found partially damaged in the fibroblast cytoplasmic vacuoles as indicated by the parasite vacuolatation. This parasite degeneration may be attributed to the presence of the melanosomes, which were regarded as lysosomes and were proven to have acid phosphatase activity (Hori et al., 1968).

The type I secretory and type II vesicular epithelioid cells (ECs) described here correspond to types A and B ECs, respectively, which were identified in sarcoid and tuberculoid granulomas (Jones-Williams et al., 1970, 1971). Presence of mucin-like secretory granules in the present type I ECs may indicate that these cells are 
more actively advanced than type A ECs (Jones-Williams et al., loc. cit.). As in sarcoidosis (Jones-Williams et al., loc. cit., Elias \& Epstein, 1968), where the majority of the ECs were of the type B, type II ECs herein were also predominant, whereas in tuberculosis majority of ECs were of type A (Jones-Williams, 1970). A fusion between types A and B ECs to form MNGC has been described by Jones-Williams et al. (1970), such fusion has not been observed in the present study.

The cytoplasm of the type II vesicular ECs contained lysosomal granules. In addition, the undifferentiated and activated monocytes, macrophages, MNGC and the type II ECs were apparently involved in the formation of the tuberculoid granulomas. Unlike Black \& Epstein (1973), our observations seem to suggest that type II ECs develop directly from undifferentiated monoculear cells after cell division. On the other hand, the origin of the secretory type I ECs, however, is still uncertain. Jones-Williams et al. (loc. cit.) mentioned that the type A ECs possibly degenerate to become the vesicular type B ECs. This suggestion also cannot be true because no structural resemblance has been made between these two types of cell, in addition to that no sequence stages of cell differentiation between these cells have been mentioned by these authors.

Type I ECs were thought to produce a protein mediator, or "granuloma factor " (Elias \& Epstein, 1968) which recruits undifferentiated mononuclear cells to perpetuate the granulomatous process, the type II ECs showing cytoplasmic vesiculation appear in situations where the granulomatous process in being brought to an end, preceding the healing by fibrosis.

\section{REFERENCES}

Alexander J. \& Vickerman K. Fashion of host cell secondary lysosomes with the parasitophorous vacuoles of Leishmania mexicana infected macrophages. Journal of Protozoology, 1975, 22, 502-508.

Beaver P.C., Jung R.C. \& Cupp E.W. Clinical Parasitology. Lea \& Febiger, Philadelphia, 1984

Berman J.D., Dwyer D.M. \& Wyler D.J. Multiplication of Leishmania in human macrophages in vitro. Infectious Immunology, 1979, 26, 375-379.

Berman J.D., Fioretti T.B. \& Dwyer D.M. In vivo and in vitro localization of Leishmania within macrophage lysosomes: use of colloidal gold as a lysosomal label. Journal of Protozoology, 1981, 28, 239-242.

Black M.M. \& Epstein W.L. Formation of multinucleate giant cells in organized epithelioid cell granulomas. American Journal of Pathology, 1973, 74, 263-274.

Black C., Fuchs H., Rappersberger K., Rollinghoff M. \& Moll N. Parasitism of epidermal langerhans cells in experimental cutaneous leishmaniasis with Leishmania major. Journal of Infectious Diseases, 1993, 167, 418-425.
Brown C., Draper P. \& Hart P.D. Mycobacteria and lysosomes: a paradox. Nature (London), 1969, 221, 658-660.

Chang K.P. \& Dwyer D.M. Leishmania donovani: Hamster macrophages interactions in vitro: cell entry, intracellular survival and multiplication of amastigotes. Journal of Experimental Medicine, 1978, 147, 515-530.

Chu A., Eisinger M., Lee J.S., Takasaki S., Kung P.C. \& EDELSON R.L. Immunoelectron microscope identification of Langerhans cells using new antigenic marker. Journal of Investigation Dermatology, 1982, 78, 177-180.

Dedet J.P., Ryter A., Vogt E., Hosli P. \& Pereira da Silva L. Uptake and Killing of Leishmania mexicana amazonensis amastigotes by human skin fibroblasts. Annals of Tropical Medicine and Parasitology, 1983, 77, 35-44.

Elias P.M. \& EPSTEIN W.L. Ultrastructural observations on experimentally induced foreign-body and organized epithelioid cell granulomas in man. American Journal of Patbology, 1968, 52, 1207-1223.

EL-SHOURA S.M. Visceral Leishmaniasis: I. Unusual interrelationships between immature erythrocytes and both parasites and mature erithrocytes. Ultrastructural Pathology, $1992,16,593-599$.

EL-SHoura S.M. Visceral leishmaniasis: III. Effect of parasitaemia level on the bone marrow ultrastructure. Applied Parasitology, 1994, 35, 61-69.

EL-Shoura S.M. Human bilharzial ureters. II. Cellular dynamic against trapped eggs. Annales de Parasitologie Humaine et Comparée, 1993, 68, 121-124.

El-Shoura S.M. \& SheIkHA A.K. Fine structure of Leishmania donovani in bone marrow aspirates from a patient with visceral leishmaniasis before and during treatment with sodium stibogluconate. Tropical Medicine and Parasitology, 1991, 42, 119-126.

El-Shoura S.M., Sheikha A.K., Al-Janadi M., Morad N., Khan A.R. \& WestmucketT A.D. Visceral leishmaniasis: II. Histiocyte ultrastructure in bone marrow associated with low level of parasitaemia and mimicking malignant histiocytosis. Applied Parasitology, 1993, 34, 259-264.

Esterre P., Dedet J.P., Frenay C., Chevallier M. \& Grimaud J.A. Cell populations in the lesion of human cutaneous leishmaniasis: a light microscopical, immunohistochemical and ultrastructural study. Virchows Archiv A of Pathology and Anatomy, 1992, 421, 239-247.

Ghadially F.N. Diagnostic electron microscopy of tumours. 2nd Ed London: Butterworths, 1985.

GHadially F.M. Ultrastructural pathology of the cell and matrix. Butterworth, Butterworth, 1988.

Hori Y., Toda K., Pathak A.M., Clark W.H.J. \& FitzpaTRICK T.B. A fine structure study of the human epiderma melanosomes complex and its acid phosphatase activity. Journal of Ultrastructural Research, 1968, 25, 109-113.

Hutt M.S.R., Köberle F. \& SAlfeder K. Leishmaniasis and trypanosomiasis. In: Tropical pathology, Spencer, H. (ed), Springer-Verlag, New York, 1973.

Jones T.C. \& Hirsch J.G. The interactions between Toxoplasma gondii and mammalian cells. II. The absence of lysosomal fusion with phagocytic vacuoles containing 
living parasites. Journal of Experimental Medicine, 1972, 136, 1173-1174.

Jones-Williams W., Erasmus D.A., Jenkins D., James E.M. \& DAvies T. A comparative study of the ultrastructure and histochemistry of sarcoid and tuberculous granulomas. In: Fifth international conference on sarcoidosis. Levinsky L. \& Macholda F. (eds.) University Karlova, Prague, 1971.

Jones-Williams W., James E.M., Erasmus D.A. \& Davis T. The fine structure of sarcoid and tuberculous granulomas. Postgraduate Medical Journal, 1970, 46, 300-496.

Kress Y., Bloom Br., Witter M., Rowen A. \& Tonowitz H. Resistance of Trypanosoma cruzi to killing by macrophages. Nature (London), 1975, 277, 394-396.

Lewis D.A. \& Peters W. The resistance of intracellular leishmania parasites to digestion by lysosomal enzymes. Annals of Tropical Medicine and Parasitology, 1977, 71, 295-312.

Mansour L., El-Marhoumy S.M., Eid M.M. \& Gawish K. A histopathological study of different clinical forms of cutaneous leishmaniasis. Journal of Egyptian Society of Parasitoloy, 1993, 23, 398-591.

Murphy G.F., Bhan A.K., Harrist T.J. \& Mihm M.C.Jr. In situ identification of $\mathrm{T} 6$ positive cells in normal human dermis by immuelectron microscopy. British Journal of Dermatology, 1983, 108, 423-431.

Murray H.W. Cell-mediated immune response in experimental visceral leishmaniasis. Journal of Immunology, 1982, 129, 351-357.

Noguiera N. \& Cohn Z. Trypanosoma cruzi: Mechanism of entry and intracellular fate in mamalian cells. Journal of Experimental Medicine, 1976, 143, 1402-1420.

Ortega L.G. \& Mellors R.C. Cellular sites of formation of gamma globulin. Journal of Experimental Medicine, 1957, 106, 627-632.

Pearson R.D., Harcus J.L., Roberts D. \& Donowitz Gr. Differential survival of Leishmania donovani in human monocytes. Journal of Immunology, 1983, 131, 1994-1999.

Pham T.D., Azar H.A., Moscovic E.A. \& Kurban A.K. The ultrastructure of leishmania tropica in the oriental sore. Annals of Tropical Medicine and Parasitology, 1970, 1, 1-7.

RidLEY M.J. \& Wells C.W. Macrophage-parasite interaction in the lesions of cutaneous leishmaniasis. American Journal of Pathology, 1986, 123, 79-85.

Schwartzman J.D. \& Pearson R.D. The interaction of Leishmania donovani promastigotes and human fibroblasts in vitro. American Journal of Tropical Medicine and Hygiene, 1985, 34, 850-855.

SMITH M.D. The ultrastructural development of the schistosome egg granuloma in mice. Parasitology, 1977, 75, 119123.

Reçu le 13 février 1996

Accepté le 19 avril 1996 